\title{
Discursive strategies that individualize: CVs and appraisal interviews
}

\author{
John Krejsler \\ Danish University of Education
}

\begin{abstract}
Professionals in education must increasingly speak of themselves through an individualizing discourse that commits them to a lifelong and life-encompassing learning and working project. By means of techniques like CVs and appraisal interviews, post-signifying regimes conjure up discursive spaces that thrive on the language of commitment, love and enthusiasm. This urges professionals to speak of their role and personality in accordance with the vision of their organization. Such discursive technology may encourage commitment, be turned into manipulative power instruments, or be reduced to shallow rituals. Beyond doubt, however, post-signifying strategies raise the stakes in organizational communication. The purpose of this article is epistemological, i.e. it intends to explore positions and strategies made available through the language provided by a certain discursive technology. It does not claim to say how this technology is actually employed empirically in particular contexts. The article draws on ideas and concepts from Deleuze \& Guattari and Foucault.
\end{abstract}

\section{Introduction}

\section{Context}

Restructuring of educational institutions since the 1980s has heralded the gradual demise of the rational bureaucratic institution, which was administered through a hierarchic centralized power structure that operated through regulations, control and grants from above. This institution is being replaced by the responsive organization that is set up with self-ownership and the obligation to sensitize itself to stakeholders' demands on market-like conditions. Continuous feedback from stakeholders-or customers-as well as increased attention to output control have thus become quintessential to the long-term survival of the organization (Ball, 1994, 2003; Peters et al., 2000; Andersen \& Born, 2001; Henry et al., 2001). Seen from an organizational

John Krejsler, The Danish University of Education, Department of Educational Anthropology, Tuborgvej 164, DK-2400 Copenhagen NV, Denmark. Email: jok@dpu.dk

This Manuscript was accepted by Roger Säljö, QSE's regional editor for Sandinavia, in January 2006. 
point of view this has brought with it more attention to continuously monitoring whether the right mix of staff is available, and whether this staff is up to date on knowledge and skills. This brings professionals under increased pressure to document that they continuously maintain and develop a competence profile that matches demands under rapid change. The principle of annuity is being dismantled when it comes to negotiating job security. And a range of new discursive technologies are being developed to suit these changing demands.

\section{Purpose}

This article aims to explore the positions and strategies that are available within a certain discursive technology that is increasingly being introduced into educational organizations in the wake of the above-mentioned developments. This discursive technology is marshalled into individualizing practices such as the curriculum vitae (CV) and the appraisal interview, which I shall scrutinize in particular, as well as a number of other practices, which are all designed to capture and mould the self within certain strategic limits. As such the purpose of the article is epistemological, i.e. it explores at a general level what it is possible to see and say when a certain discursive technology is employed. It does not claim to say how this technology is actually employed empirically in particular contexts. Empirically one will see that this technology is positively embraced and encourages commitment among professionals in some places, whereas in other places it leads to resistance, is turned into manipulative power instruments, or may simply be reduced to shallow rituals. Beyond doubt, however, the post-signifying strategies, as I call them with reference to Deleuze \& Guattari (2002a), raise the stakes in organizational communication considerably.

I find it extremely timely to make explicit the epistemological space for manoeuvring that the language of such individualizing technology contains in order to understand more fully how professional identity and autonomy are currently being transformed in educational organizations. We live in a time when new dominant technologies set the conditions for how professionals maintain employment and become successful. Recurrent assessment, contractual agreements and appeal to personal commitment are on the rise as instruments that govern how professionals can carry out their work (e.g. Ball 1994, 2003; Foucault, 1994/1984; Marshall, 1996; Rose, 1999/1989; Andersen, 2003; Krejsler, 2005).

\section{Theoretical framework}

The article draws inspiration from Deleuze \& Guattari's conceptual work on signifying and post-signifying regimes (2002a). These analytical constructs, which are alien to the inner logic of dominant individualizing technology, allow us to make this technology appear less self-evident, which is a precondition for dismantling its seductive character and facilitating contestation and alternative strategies. The concepts thus become well suited to deconstruct dominant individualizing technology in late-modern organizations 
A signifying regime may initially be described as an overcoded and centralized regime. It consists of signs that perpetually refer to one another within a closed circuit. The signifying regime represents a dominant way of organizing populations in industrial society, for which Deleuze designates the term 'disciplinary society' with reference to Michel Foucault (Deleuze, 1995/1990; see also Foucault, 1977). It could be exemplified by the religious sect, the industrial school, the factory, and military barracks. They all function by means of a limited number of central dogmas and rites that cannot be questioned. These dogmas and rites perpetually overcode their surroundings by multiplying themselves as signs in everything that is said and done. All available positions within the regime and all interpretations of events in the surroundings are coded as comments that continually confirm the truth of the key dogma.

Industrial school may thus be described as a signifying overcoded space, i.e. an enclosure where a few dominant différences ensure that only a limited number of welldefined positions are available for individuals to fill out. Included subjects must code their bodies, minds and expectations according to the logic of these privileged différences: teacher-student, school-home, lesson—break and so forth. These privileged différences set the stage for a particular choreography through which coordinated activities and speech are marshalled into continuous practice.

The concept of the post-signifying regime attempts to capture the increasingly dominant way of organizing human bodies in what is often referred to as the 'knowledge society', for which Deleuze designates the term 'control society' (Deleuze, 1995/ 1990; Hardt \& Negri, 2000). The post-signifying regime has no centre, no black hole that can engulf and reduce everything in its surroundings to a limited number of privileged différences and dogmas. Instead, this regime works by encouraging its subjects to identify with its aims and requirements as if they were their own. Therefore, the post-signifying organization mainly seeks to influence how its employees construct their points of subjectivation, i.e. the perspectives that motivate them. It seeks to guide and stimulate its subjects' desires by appealing to their passionate commitment. As examples of points of subjectivation, Deleuze \& Guattari mention the power of attraction of the shoe for the fetishist or the facial traits of the beloved for the lover. Similarly, contemporary education systems exploit the power of attraction of the promise of self-realization in order to influence how individuals construct their points of subjectivation in ways that are designed to align their passionate commitment to organizational goals. If successful, such an alignment is followed up by innumerable dialogues concerning the newly formulated desires and needs of these individuals. This strategy thrives on the constant appeal to each individual subject's responsibility for his/her own learning processes. The individual subject is supposed to end up being committed to an action plan that is meant to feel like the means to realize his/her own ambitions.

By taking as a point of departure the hypothesis that organizations are experiencing a transition from largely signifying to largely post-signifying regimes, my aim is to be able to explore new aspects of phenomena that have become so selfevident that they no longer inspire creative and critical thinking. These phenomena 
include professionals, education, the transition from industrial to knowledge societies (Deleuze \& Guattari, 1996/1991; 2002a; Foucault, 1971, 1993, 1994/ 1984).

Within the scope of this article I shall explore more precisely the immanent epistemological universe that is conjured up by techniques such as the CV and the appraisal interview, to which could be added a large array of similar techniques (psychological tests, formative assessment, portfolio, logbooks and so forth). I shall do this in light of the hypothesis that this kind of technology sets new conditions for how professionals can think and talk about their identity and purpose, and that this change can be conceived of as a gradual transition from overcoded signifying technologies towards individualizing post-signifying technologies. The organizational logic is that by installing appropriate points of subjectivation in the organization's subjects, motivated and flexible individuals are produced, i.e. individuals who continually adapt their selves in appropriate ways to changing conditions and perceive this to be of their own volition.

\section{Curriculum vitae and other self-declaration technology}

The first exploration concerns the discursive technology whereby individuals are instigated to prepare and work on their selves in order to achieve status as subjects within a post-signifying regime (Foucault, 1994/1983; Simola et al., 1998). As the negotiation of the point of subjectivation is at stake here, it is subsequently important to make the individual who seeks entry to an organization describe something about him/herself in relation to the position that she/he desires to occupy within the regime. The individual must reveal his/her character as a subject of desire before it can be assessed whether she/he should be granted entrance to the post-signifying regime in question. In recent years an impressive array of techniques has been developed that the individual is offered or demanded to take in use in order to stage his/her request for entry. These include CVs, psychological tests, portfolio and logbooks. I shall focus on exploring at a general level the immanent universe of the $\mathrm{CV}$ illustrated with examples from website guides to writing the successful CV.

\section{The $C V$ as a technique to master transition from individual to dividual}

If you apply for a position as a teacher at a school or a college you must among other requirements elaborate a curriculum vitae and possibly even attach a portfolio-like selection of diplomas, documentation and products. In toto this serves to make probable that you are qualified in the best of ways to infuse desire into the subject position that is currently vacant within a post-signifying regime.

Here various website services among others that specialize in job-seeking and selfpresentation will be able to provide useful tips and guidance concerning the large variety of ways in which a successful CV can be elaborated. One of these services states the following about the character and purpose of a $\mathrm{CV}$ : 
A CV or curriculum vitae is a marketing tool. With your CV you will be able to promote yourself. Imagine the $\mathrm{CV}$ as being a brochure that will list the benefits of a particular service. The service being your time and skills! (Retrieved from http://www.cvtips.com/ 11 November 2005)

If you are able to stage your self in a sufficiently attractive way to the eyes of the regime's assessment committee at this first instance, then you will be summoned to a second assessment to demonstrate the virtues of your self, i.e. a job interview. The job interview is usually staged as a round-table dialogue in an apparently informal setting. Its dynamic is driven by a mixture of dialogue, examination and self-promotion.

Within the signifying regime of school in the industrial society a standardized college diploma would normally suffice. Its eloquent stamp of authority by definition proves that you have subjected your self to be formed according to the rigours of a similar signifying regime during your training (Foucault, 1977). Here requirements of detailed self-promotion are usually not applied.

In contrast, the $\mathrm{CV}$ opens up to innumerable (in)dividual variations in order to connect an (in)dividual to a particular position within a post-signifying organization. On the one hand this is an offer to the applicants to construe their selves, their life narratives and their desires to form exactly the profile that they desire to employ in order to enter the announced position. On the other hand they must include in their calculations that there may be a considerable number of other applicants. Therefore, you must adapt the description of your self to the image that you calculate that the organization wants to see and hear. The above-mentioned website service thus states:

When writing a CV look at it from your employer's point of view. Would you stand out against the competition (the other candidates) and would the manager want to talk to you for a possible job? You have to ask yourself these questions when writing your CV or curriculum vitae.

Prior to setting up your CV you must thus research and reflect upon questions like: What is the probable number of serious applicants? How well does your competence profile fit with the announced position? Having done that you must make a calculation on how much you dare to gamble and how much you want to adapt to what you think is expected of you. Obviously such deliberations depend to a large degree on how much you want or need the job. On another website guide to writing the successful CV and job application it says:

There is no right or wrong way to write an application. The way you elaborate it will, however, contribute to transmitting an image of who you are, and thus mirror your personality. Your style of writing thus allows you to make a conscious choice as to how you wish to appear. Whether you want to appear traditional, different, of sparkling wit, serious, thorough, profound or creative will thus depend upon your personality and your preferences. (Pernille Skanderup: 'The Art of Writing a CV and an Application' retrieved from http://www.ddc.dk/DESIGNVIDEN/artikler/CV_ansoegning 11 November 2005 [author's translation])

Against this background it makes sense, according to Deleuze, to claim that subjects, who used to appear as individuals in industrial society, must increasingly understand themselves as dividuals in knowledge or control society (Deleuze, 1995/1990; Hardt 
\& Negri, 2000). Individual means indivisible. In this context it refers to images of the subject as a firm entity with a core identity, which was reinforced by the isomorphisms between steady positions within different but homologously structured signifying regimes in an industrial society. Within the enclosure of a traditional nation-state, one could thus talk of the experienced long-term coherence between being a son within the nuclear family, a pupil in school, a worker in the factory, and then a father within the nuclear family and so forth. Dividual means divisible. It refers to the phenomenon whereby subjects must increasingly and simultaneously divide their attention between a number of different understandings of who they are that do not necessarily make up over time a coherent experience of who they are. Giddens claims that in an increasingly globalized late-modern society man must first and foremost be able to keep a narrative going about his/her self, a narrative that must be continually worked on reflexively, and a narrative that most probably must be revised on several occasions during a life's span due to continually changing conditions in work, private life and society as such (Giddens, 1991).

Consequently, subjects must increasingly understand themselves as dividuals, as they construe their CVs for different occasions over time. At each instance they must reflect on how the fragments of their lives can be put together in new ways in narratives that express the self-promotion that they calculate will be most effective as they are assessed by a particular organization. If you are in great need of the job or your prospects of getting it are slim, then you are more likely to feel tempted to set up a self-promotion that deviates considerably from how you understand yourself in other areas of your life. In the case that you get the job in spite of slim chances and you are obliged to stay committed to the self-promotion you initially made in relation to the organization's vision, then you will possibly make a virtue out of necessity and revise important aspects of the narrative about your selves in other life arenas. Another option may be to keep several narratives going about your selves simultaneously that are not mutually compatible.

It could be argued that humans have always acted out roles. Therefore, the abovementioned example does not indicate anything that is qualitatively new, and does not justify the claim of a transition from individuals to dividuals. The point, however, is that post-signifying technology like the $\mathrm{CV}$ does not allow the same degree of subjective distance to available subject positions as is normally the case in signifying regimes. The post-signifying regime demands that you infuse and reflect upon your role with personal commitment. Your competence profile must be orchestrated as an integrated whole of academic, social and personal competences. This is contrary to signifying systems that overcode in advance the scopes of action that are assigned to available positions.

As an illustration of the post-signifying regime the Danish State Department of Administration writes in its annual report and in a language that you would previously not have expected to see in annual reports from state departments $(1987$, p. 6):

It is furthermore of importance that the employee does not feel reduced to being merely the holder of a professional postition, that she/he in addition feels welcome and appreciated with the personality and the oddities that each individual unquestionably disposes of. 
Respect and appreciation are not only a question of rosy words and positive mention, it has equally much to do with critique - constructive critique - ... that each individual is taken seriously as a person and as a professional. (quoted from Andersen \& Born, 2001, p. 87 [author's translation])

\section{The art of moderating the post-signifying regime by counter-signifying action}

The counter-signifying perspective attracts our interest because of its utility as a nomad-like war machine that is useful in fighting, contesting or cutting through larger or smaller parts of territories that are dominated by signifying or post-signifying regimes (Deleuze \& Guattari, 2002a, 2002b). It is made to handle unstable and vulnerable conditions that arise from relations of opposition to the state apparatus or individualizing regimes that occupy, dominate and overcode the territories that surround us.

The counter-signifying regime is not construed around a central point of gravitation that gathers and overcodes all available elements to an all-encompassing totality as is the case with the signifying regime. Neither is it construed through processes of individualization that gather motivation and commitment from self-imposed albeit mandatory points of subjectivation, as is the case with the post-signifying regime. The counter-signifying regime is like the nomadic tribe that keeps its attention fixed on breaks, transitions, migrations or opportunities for mutation or metamorphosis that signifying or post-signifying regimes in particular make possible. Counter-signifying regimes in modern society could be exemplified by squatters, gang and mafia organized groups, various forms of parallel economies (black markets, moonshine activities and so forth).

From the point of view of the counter-signifying perspective the CV is initially a coercive technique that seeks to oblige the dividual to engage all aspects of his/her personality in a complex strategic game, in case she/he wants to acquire the status of subject, i.e. employment, within largely post-signifying regimes. Mastering that game requires formalized training and considerable amounts of on-site experience of such regimes. In order to set up a satisfactory $\mathrm{CV}$ the dividual is thus required to engage in reflections on how previous job positions, educational experience, journeys abroad, hobbies and miscellaneous personal experience are to be put together in order to make up the appropriate mix that promotes one's self in accordance with the stakes one is ready to risk in order to get the position announced. It may be useful here to consider concocting post-signifying and counter-signifying elements and bringing them together into a semiotic mix, a game about promoting one's self where sincerity, bluffing, self-marketing, rhetorical clout, ethics and integrity must be balanced in a risky process with high stakes. Creative wording may be useful in making a relatively unexciting period of unemployment look like intensive personal development. Participation in a relatively meaningless course may have to be shone up to look like something very central that boosts one's profile in relation to the vision and needs of the organization in question. A third website service reflects very explicitly on such strategic issues:

Omitting to say things that will obviously diminish your chances of being considered for a job at stake is not the same as being dishonest. But you should never lie concerning your 
educational and occupational background as such things can be found out. And do not forget that if you are summoned to a job interview you will be better off if you can match your application/CV. (retrieved from http://cv.ofir.dk/tips_til_jobsoegning/ ansoegning_og_cv/raad_og_tips_om_ansoegning_og_cv.asp?atab=3 11 November 2005 [author's translation])

Here it seems potentially fruitful to think of the counter-signifying perspective in terms of a war machine that must gather directed force in order to invade a largely post-signifying regime (Deleuze \& Guattari, 2002b). The dividual nomad starts out by investigating the organization's defence systems in order to develop the most powerful invasion strategy. At times the strategy of open dialogue may be preferable, at other times the strategy of the Trojan horse. After having made your way into the organization you may consider restructuring your war machine according to the potentials that are available in a new strategic situation. Having entered a new regime you will most likely discover that various factions navigate in accordance with different strategies in order to make the best of the framework that largely post-signifying regimes allow.

It could furthermore be argued that this kind of semiotic mix of post-signifying and counter-signifying strategies represents calculating competences that are essential to master to be able to serve the targets of late-modern organizations that require you always to serve stakeholders by means of consumer-friendly rhetoric. By showing mastery of such strategies you make explicit that you know how to deal with social dominance, which is a basic element in all educational organizations, simultaneously making it legitimate as a result of dialogic processes (Krejsler, 2002, p. 60).

This is not to be understood as a cynical and opportunist life strategy. On the contrary, it just makes explicit that the war machines, which different subjects must mobilize and continuously update, consist of a multitude of weapons that are experienced as necessary in order to deal with and handle a complex strategic situation (Foucault, 1978; Deleuze, 1995/1990; Ball, 2003):

- political aptitude in navigating strategically among management, colleagues, clients, administration, the public and so forth;

- ethics, solidarity, empathy and dialogue in order to truly participate in building relations with colleagues, management, clients and other stakeholders that support personal integrity and social coherence;

- aptitude in balancing the professional role with one's position as a private person in order commit oneself to the extent one finds appropriate on the one hand, and on the other hand to be able to keep the distance from one's work that one finds suitable.

\section{The appraisal interview, contractual agreement and other commitment technology}

Upon enrolment as a subject in a largely post-signifying organization the issue arises of how the dividual is motivated to commit his/her self to want to achieve the optimum for the organization. As opposed to the signifying regime it is not the obligation 
to carry out one's duties and assigned tasks in close compliance with institutional regulations that is the defining feature. It is rather a matter of being able to manifest that you yourself have of your own volition chosen to do in your own way that which the organization wants done, as was clearly exemplified in the case of the CV.

You will be defined as the responsibilized employee. Consequently, the subject's commitment to the organization is something that should be manifested in dividual initiatives at appropriate intervals that, in the words of Andersen \& Born (2001, pp. 148-149), turn into expressive signs of the subject's love for the organization. It is emphasized that management and professionals develop visions and goals for the organization in joint collaboration.

\section{Contractual agreement as strategy}

Andersen (2003) points to the trend that management of relations in organizations is increasingly carried out by means of contractual agreement. His prime concern is the relation between professional and client. It can be argued, however, that similar trends are prevalent in the bulk of technology that is employed in order to commit the professional as a subject to the organization (Krejsler, 2002, 2005). This follows from the logic of the restructuring that since the 1980s has turned state and municipal institutions into organizations that are defined as self-governing units. Within these units each (in)dividual professional subject is discursively staged as a free agent who negotiates contracts with management, teams of colleagues, clients/ consumers and external stakeholders. Such social contracts are typically staged as open dialogues where each dividual subject is urged to exercise commitment, creativity and personal initiative in order to accomplish the organization's vision as a joint venture. Personal and professional issues turn into two sides of the same coin.

Amidst this discursive preoccupation with free agents and self-promotion it becomes paramount, however, not to forget that as a social practice an employment relationship is basically an asymmetric relationship, i.e. one where an organization employs a dividual in its own legitimate self-interest in order to fill out a more or less well-defined subject position with plenty of strings attached (Ball, 1994, 2003; Rose 1999/1989; Krejsler, 2005). However, such asymmetric features are usually not explicitly recognizable in the language made available by post-signifying contract techniques. These features do, nonetheless, become very recognizable indeed if the subject makes a faux pas or appears as a free subject in an erroneous way. If such incidents take place on a sufficient number of occasions within the organization this will make the subject appear increasingly inappropriate. The post-signifying regime does not fire or sack employees. In the words of this regime's language it is, rather, recognized that some subjects have chosen to develop competence profiles that no longer match the needs of the organization. In that way such subjects have placed themselves on the organization's periphery and by implication made it obvious that they want to seek exciting challenges elsewhere. Andersen \& Born express this point lucidly in saying: 
Under such circumstances it becomes rather embarrassing if one does not seek new pastures and asks to be set free. If organizational management has delegated liberties to employees to develop themselves and take initiatives, and those liberties have not been exploited, then those employees have virtually excluded themselves. (2001, p. 171 [author's translation])

\section{The appraisal interview}

By exploring at a general level the immanent universe of the appraisal interview, we shall now see how such post-signifying management technology of relations is constructed through a language of mutual contractual agreement. The appraisal interview is an organizational demand that is simultaneously marketed as an offer to conduct an open dialogue between management and employee. It is a technique that sets the stage for a dialogue between two subjects that are placed in an inescapably asymmetric relation to each other, formally as well as in practice. Its purpose is suspended between the organization's demand (personified in the leader) of its subjects to optimize realization of organizational goals and the employed dividual's self-promotion in the version that she/he chooses to bring out into the open, all stakes taken into consideration.

It says, for instance, in 'The Copenhagen University Appraisal Interview Guide', which is quite similar to standards at other Danish educational organizations, that the purpose of the appraisal interview:

$\ldots$ is to ensure coherence between the general goals for staff and each individual coworker's accomplishment of assignments and competence development. (Copenhagen University, 2005-http://www.ku.dk/puma/Medarbejderudviklingssamtaler/Vejledning. doc [retrieved on 1 July 2005; author's translation])

Within the framework of a largely post-signifying regime this equals an appeal to the employed subject to invest commitment to and passion for the ongoing subject construction for that purpose. Consequently, it is emphasized in the same guide how important it is:

for the dialogue that is going to take place that both parties have prepared for the dialogue and are ready to engage in an open and equal dialogue and that realistic wishes and demands are put forward (author's translation).

The dividual is thus obliged to market him/herself as a self that disposes of initiative, visions, plans and concrete targets for his/her own competence development that confirm the bonds of love that bind the subject and the organization together. This does not mean, however, that disagreement may not be expressed during the appraisal interview. For if the employee complies with the explicit goals of the organization in an overly adaptive way, she/he risks in an almost embarrassing manner showing him/ herself to be a conformist and uncritical employee that openly sweet-talks the regime. Hereby the requirement to promote oneself as an independent dividual with strong stands and passions, which can be turned into assets for the organization, is violated.

To encourage that this discourse about open dialogue, desires, commitment and initiative will take place the appraisal interview technique is staged as a confidential 
space for dialogue. In order that the subject's sincere opinions and hidden resources may be elicited for the benefit of the regime the dialogue must be stripped of some of its formal attire that may otherwise inhibit the free flow of exchange of ideas among employer and employee. Therefore, the following is explicitly inserted into the aforementioned guide: 'As a point of departure the dialogue is confidential and there must be agreement as to which parts may be transferred to third parties.'

However, this attempt to strip the appraisal interview of some its formal attire is not without problems. Inadvertently it points to a number of other formalities that disclose the highly charged strategic stakes and conflicts of interest that the appraisal interview technique seeks to bridge or disregard as it elicits sincerity and hidden resources. Guides to appraisal interviews thus almost always include statements that both parties should prepare themselves well as far as future work assignments, salary issues, working climate and personal issues are concerned. Furthermore, the procedures for conducting the appraisal interview are the object of extended debate among management, union representatives, collaboration committees and so forth. The expediency of insisting on this degree of formal framework is closely linked to the fact that a dialogue which zooms in on the employee's competence development and mutual wishes in relation to his/her working performance also touches on the conditions for future job security, albeit often indirectly.

Another aspect of this formal attire is related to the issue that the appraisal interview is contractual in the sense that it ties both parties to obligations. Therefore, what has been agreed upon, what has been said and what must be accomplished thereafter must be explicit. Otherwise the employee risks being left uncertain as to how the employer interprets or wishes to interpret what she/he has heard during the interview. Or the employer risks being exposed to unfair levels of expectation due to unclear agreements. Such risks may lead both parties into being overly cautious about what they dare say. Consequently, it is explicitly stated in the afore-mentioned guide as well as in numerous other guides to appraisal interviews that:

It is a pre-condition for well-conducted appraisal interviews that explicit guidelines exist as far as confidentiality and follow-up procedures are concerned. Once the appraisal interview is terminated employer and employee must have formulated what has been agreed upon and how agreements are to be followed up during the time to come (author's translation).

In 1992, The Danish School of Public Administration issued a publication titled 'Staff Development - a guide to state authorities and institutions' which summarizes aptly in the language of the appraisal interview discourse the strategic space that this technique occupies:

The appraisal interview is a good opportunity to discuss and plan the employee's work performance and development. The employee acquires influence and co-responsibility as far as decisions on the organization of work assignments, courses, job training, transfers and the like are concerned, and the appraisal interview gives the employer a concrete opportunity to exercise his/her staff responsibility.... The employee is trained in discussing his/her own work performance, in unveiling weak and strong sides and in participating in the planning of his/her own development. (Quoted from Andersen \& Born, 2001, p. 94) [author's translation] 
In an increasingly unpredictable society that demands flexibility at a local level social contract techniques such as the appraisal interview thus tend to replace the kind of centralized formal judicial governance that applied to signifying bureaucracies and that regulated institutions from above and in detail across the nation. This does not indicate, however, that central control has necessarily diminished, just that it is increasingly delivered locally in decentralized forms. Increasing proliferation of quality assurance procedures to assure central authorities that the organization still deserves grants and other favours from the central level thus indicates that the central pressure to perform has hardly lessened. Educational organizations must comply with national strategies to assure international competitiveness in a globalized knowledge society, as defined by the OECD, WTO, EU, UNESCO, as the Bologna process, PISA and CERI assessments of national achievements clearly testify (e.g. Ball, 1994, 2003; Henry et al., 2001; Wright, 2005).

As a social contract technique the appraisal interview is characterized by raising the stakes for what it is possible to talk about between employer and employee within the framework of a formalized employment relationship. All things considered this should considerably increase the availability to the employer of knowledge of the thoughts and wishes of employees, which could serve the organization as well as its subjects. This applies in particular where a good working climate, good chemistry between employer and employee, the experience of job security, resources to realize competence development and so forth are sufficiently abundant. Where that is not the case the appraisal interview may well be turned into a tedious and strained ritual for both parties. At worst the appraisal interview may acquire the features of intimidating interrogation and a control measure in relation to the employee. Furthermore, it could be argued that the employee who performs at peak levels will most probably experience the appraisal interview as an opportunity as opposed to the employee who is not functioning so well. If, however, there is a good working climate within the organization even the latter may profit from the appraisal interview as an opportunity to put into words problematic issues in an appeal for assistance in dealing with an unpleasant situation.

\section{Counter-signifying strategies}

According to Deleuze \& Guattari (2002a) post-signifying regimes primarily seek to influence how subjects construct the perspectives and ideas that motivate them, i.e. their points of subjectivation. From this point of view the purpose of the appraisal interview is a matter of coming to agreement about the points of subjectivation that may guide the subject's future commitment and activities. This agreement, which is vested with the attributes of a contract, preferably appears as a voluntary act of consent.

The appraisal interview and the social contract may undoubtedly yield good results assuming that conditions for dialogue are good and that the parties' wishes and interests are of a similar nature. If that is not the case, however, the bulk of legitimacy disappears in claiming that subjects of their own free volition commit themselves passionately to perform what certain contrived points of subjectivation suggest. 
When what the employee sincerely believes conflicts with that which she/he is supposed to sincerely believe, she/he may be better off seeking assistance within the realm of counter-signifying strategies. Here the employee may choose 'the open invasion strategy', albeit seldom conducive, of overriding the leader and organizational visions and goals. In making that choice she/he must obviously consider whether she/ he disposes of sufficient resources, be this in the form of convincing ideas, overt or covert alliances with colleagues or other potentially powerful stakeholders and so forth.

Alternatively, the employee may choose 'the Trojan horse invasion strategy'. Here the employee hides in the first instance his/her real intentions until the moment is ripe and simulates/pretends that what she/he thinks and does complies with the management's strategy. In the meantime she/he develops alternative strategies, nourishes intrigues and builds up alliances that she/he hopes will gradually upset the relative balances of power within the organization. This strategy, which often involves high and risky stakes, demands good tactical skills in the arts of argumentation, seduction and manipulation. Within an organization characterized by mutual trust and a good working climate such a strategy may inflict irreparable damage on relations among colleagues and contribute to undermining one's own ethics and integrity. Things present themselves differently, however, within an organization where the management's post-signifying strategies are already recklessly employed to intensify employees' bonds to the organization without giving them a real say in strategies that simulate participation. The counter-signifying perspective would claim that this already equals a state of war where the objective is to de-territorialize the opponent's resources and re-territorialize those in one's own favour, not in the form of mutual exchange but rather as occupation or conquest. If one is able to gather a horde of adherents whose strategies are internally coordinated in relation to exploiting, for instance, the strategic space of the appraisal interview, they will most probably increase their say in how organizational goals are implemented in daily practices.

Finally, Deleuze \& Guattari (2002a) evoke the notion of pre-signifying or so-called primitive regimes. They are made operational not so much through signs as by natural or bodily codings, i.e. a plurality of corporeality, gestures, rhythmic sequences, dances or rites and so forth. The effects of this regime have proved to be quite efficient in keeping at bay aspects of signifying as well as post-signifying regimes. The strategic use of silence, rhythmic sequences among colleagues like 'Well, well!' or other implicit bodily signs or gestures would constitute relevant examples. What in union jargon is called 'work-to-rule' actions also contain elements of pre-signifying strategies: the rhythm of work is slowed down, the speed whereby emails and requests are responded to is diminished and so forth. A group may also bring into use pre-signifying elements in an almost ritual way at social gatherings, through bullying or ignoring certain people.

Subjects may also choose the more passive distraction strategy of saying one thing and keeping silent about what they really do. Here subjects say explicitly what the organization and management want to hear but continue to go about their business 
as usual. This strategy is placed somewhere between a counter-signifying and a presignifying approach. It could contribute to enhancing inertia in large organizations in particular when it comes to resisting undesired demands. This strategy, however, has the drawback to it that it is mostly a purely defensive strategy. Therefore, it is hardly conducive to impacting explicitly on agendas and meetings where debates and decisions about the organization, its visions, goals, regulations and explicit practices are carried out.

It probably applies to most of the above-mentioned counter-strategies that dividual strategies tend to be less successful than collective strategies.

\section{Navigating within the post-signifying regime: summary and perspectives}

By means of the analytical construct of post-signifying regimes in particular, this article has scrutinized at a general level the discursive universe of individualizing techniques - the CV and the appraisal interview in particular - that are of significance in understanding modern organizational management. These techniques convey the image that by entering into open negotiations employers and employees will eventually arrive at mutual agreements that dissolve disagreements and make everybody realize the benefits of pulling in the same direction. Such negotiations are orchestrated in the language of dialogue, confidentiality and democratic procedures that simulates negotiations among free contracting parties.

It has also been argued that the asymmetric character of power relations in organizations will most probably tend to make employees adapt their self-promotions to what they believe the organization expects of them. The extent to which one adapts, however, is dependent on what one dares to put at stake, which is usually highly dependent on the extent to which one needs the job.

In post-signifying terms, the key issue at stake is the organization's interest in intensifying its subjects' passionate commitment, which makes it difficult to keep a distance from one's job (Foucault, 1978; Deleuze, 1995/1990; Krejsler, 2004). Concerning the social contract, Andersen (2003, p. 179) even talks about double tutelage in the sense that this post-signifying technology does not only relate to the dividual as a subject who is to be subjected to an organizational action plan. It furthermore seeks to impact upon this subject's relation to his/her self as a subject.

The discursive demand of this dominant individualizing technology that commits one to processes of dialogue in asymmetric power relations thus raises the question of how to deal strategically with such attempts to monopolize language. To what extent can you go ahead and do what you really want? To what extent are you obliged to do things that you do not want to do? To what extent can you negotiate a balance between organizational demands and your own wishes? And to what extent will you end up making in the presentation of your self a virtue out of necessity in order to make ends meet that would not otherwise meet?

All this sparks off the question of whether what you yourself want reflects some sort of personal autonomy that is independent of the post-signifying regime, or whether what you express as your wishes in this regime's language is rather to be understood 
as an integrated part of the modus operandi that enables the post-signifying regime to exploit fully its subjects' commitment, passions and desires.

This brings us to the core of the argument that Deleuze \& Guattari (2002a) advance with reference to the Dialectic of Enlightenment, which goes: The more you obey the statements of the dominant reality the more you simultaneously become the subject of these statements in a mental reality. Thereby you turn into the slave of yourself by obeying in the end nobody but your self.

\section{Constructing alternatives}

Are alternative freedom practices possible that move beyond merely shaping one's self in the image of the post-signifying regimes, within which one already acts as a subjected subject more or less voluntarily (Foucault, 1994/1984)?. In the affirmative, what then are the potentials of counter- and pre-signifying strategies when it comes to thinking differently about the subject positions that one can occupy?

In order to be able to think about ourselves differently as subjects within particular regimes the first requirement is that we raise ourselves level with the complexity of the strategic spaces within which we manoeuvre as subjects (Deleuze \& Guattari, 1996/1991; Foucault, 1993). To develop strategic potentialities within an organization, or the war machine as Deleuze \& Guattari (2002b) named it, we must match the constellation of power relations that affects what can be said and what can be done within the organization. Among other things relevant knowledge concerning the balances of power among different stakeholders must be considered: Who owns of the monetary, political and cultural capital that sets the framework for the organization that one operates within? (This includes external stakeholders that represent legislation, administrative practices, the market, the local community and so forth.) What are the organization's history, its factions, formal and informal pathways to influence? Without such considerations, subjects' strategies easily end up holding naive misconceptions about their influence or lack of influence, which will inevitably lead to distressing defeat and the danger of resignation or exclusion. These appear to be necessary preconditions to consider in order to create an impact that makes a difference within the organization. This can be done by means of strategies like dialogue, invasion, symbiosis, metamorphosis, argumentation, seduction and so forth.

As we have seen, counter-signifying perspectives enable us to think in terms of (in)dividual as well as collective strategies. And in relation to the highly volatile post-signifying regimes one can only give limited direction to one's endeavours by referring to objective criteria. One must continuously be ready to change perspective to be able to see matters from a different angle in order to prove equal to the changing conditions in one's surroundings. Continuous demands for organizational reform thus seem to favour dividuals who are mobile within structures that are highly volatile.

Here, no doubt, one is better off adjusting one's dreams and wishes to the mighty counterparts that set the agenda for educational organizations and define their roles 
in society. This agenda has been marshalled into dominant new administrative practices that go under the names of restructuration or New Public Management (Peters et al., 2000; Henry et al., 2001; Krejsler, 2005). CVs, appraisal interviews, social contracts, quality assurance and other similar measures thus signal fundamental changes in the conditions for maintaining educational organizations as I have argued in this article.

The arguments in this article seem to favour a figure that one may designate by the term the agonic professional (Krejsler, 2006; see also Foucault, 1994/1984; Deleuze, 1995/1990). The agonic professional, whose subjectivity is itself a creation of the contexts that she/he moves and has moved among, chooses his/her weapons according to the circumstances of the battlefield where she/he is present in order to protect and develop some sort of integrity. She/he faces management and colleagues without marginalizing him/herself within a field that continuously oscillates between states of routine, reform, intrigues, manipulation, dialogue and commitment. She/he enters into dialogues and joins in collegial struggles when conditions seem appropriate. The agonic professional manoeuvres by employing an appropriate mixture of commitment, ironic distancing and a sense of humour, which it is hoped contributes to inspiring intercourse with management, colleagues and clients. She/he may turn into a nomad if his/her space for manoeuvre is reduced to simple confinement. Under such circumstances the nomad scans the strategic situation and considers other fields.

The agonic professional obviously represents a somewhat utopian figure that presupposes overview, resources, an advantageous market situation and numerous other elements that are rarely at professionals' disposal simultaneously. I would argue, nonetheless, that he/she may serve as an inspiring figure that helps by hinting at strategies and competences that are necessary for continuous development in order to master the post-signifying battlefield.

\section{Notes on contributor}

John Krejsler (PhD MEd) is an Associate Professor at the Danish University of Education, Department of Educational Anthropology. His research interests are higher education, teacher education and epistemology (poststructural and critical theory), as well as professional subjectivities and power relations in education.

\section{References}

Andersen, N. Å. (2003) Borgerens kontraktliggørelse (Contractualization of the citizen) (in Danish) (Copenhagen, Hans Reitzels Forlag).

Andersen, N. A. \& Born, A. W. (2001) Kerlighed og omstilling_Italescettelsen af den offentligt ansatte (Love and restructuring - The discourse about the public employee) (in Danish) (Frederiksberg, Nyt fra Samfundsvidenskaberne).

Ball, S. J. (1994) Education reform: A critical and post-structural approach (Buckingham, UK and Bristol PA, Open University Press).

Ball, S. J. (2003) Professionalism, managerialism, and performativity, in: L. Moos \& J. Krejsler (Eds) Professional development and educational change (Copenhagen, Danish University of Education Press). 
Copenhagen University (2005) Vejledning til medarbejderudviklingssamtalen på Københavns Universitet (The Copenhagen University appraisal interview guide) (in Danish). Available online at: http://www.ku.dk/puma/Medarbejderudviklingssamtaler/Vejledning.doc (accessed 1 July 2005).

Deleuze, G. (1995/1990) Postscript on control societies, in: Negotiations (1972-1990) (New York, Columbia University Press).

Deleuze, G. \& Guattari, F. (1996/1991) Qu'est-ce que la philosophie? (Paris, Les Editions de Minuit).

Deleuze, G. \& Guattari, F. (2002a) 587 B.C.-A.D. 70: On several regimes of signs, in: $A$ thousand plateaus (London \& New York, Continuum).

Deleuze, G. \& Guattari, F. (2002b) 1227: Treatise on nomadology: The war machine, in: A thousand plateaus (London \& New York, Continuum).

Foucault, M. (1971) L'ordre du discours: leçon inaugurale au Collège de France prononcée le 2 décembre 1970 (Paris, Gallimard).

Foucault, M. (1977) Discipline and punish: the birth of the prison (New York, Pantheon Books).

Foucault, M. (1978) The history of sexuality: the will to knowledge (New York, Pantheon Books).

Foucault, M. (1993) Qu'est-ce que les Lumières?, Magazine littéraire (Thème: 'Kant et la modernité), No. 309 (avril [Paris]), 61-74.

Foucault, M. (1994/1984) The ethic of care for the self as a practice of freedom: an interview with Michel Foucault on January 20, 1984, in: J. Bernauer \& D. Rasmussen (Eds) The final Foucault (3rd edn) (Cambridge MA, MIT Press).

Foucault, M. (1994/1983) On the genealogy of ethics: an overview of work in progress, in: P. Rabinow (Ed.) Foucault-Ethics: subjectivity and truth. Essential works of Foucault 1954-1984 (Vol. 1) (New York, Penguin).

Giddens, A. (1991) Modernity and self-identity: self and the social in the late modern age (Stanford, Stanford University Press).

Gore, J. M. (1998) Disciplining bodies: on the continuity of power relations in pedagogy, in: T.S. Popkewitz \& M. Brennan (Eds) Foucault's challenge (New York \& London, Teachers College Press).

Hardt, M. \& Negri, A. (2000) Empire (Cambridge, MA and London, Harvard University Press).

Krejsler, J. (2002) Teacher professionalism and terminology of self-determination, Nordic Educational Research (Nordisk pedagogik), 22(1), 25-37.

Krejsler, J. (2004) Becoming individual in education and cyberspace, Teachers and Teaching: Theory and Practice, 10(5), 489-503.

Krejsler, J. (2005) Professions and their identities: how to explore professional development among (semi-)professions, Scandinavian fournal of Educational Research, 49(4), 335-357.

Krejsler, J. (2006) Professionel eller kompetencenomade (Professional or competency nomad) (in Danish), Nordic Educational Research (Nordisk pedagogik) (Theme: Dominant discourses and professions), 26(4), 298-308.

Henry, M., Lingard, B., Rizvi, F. \& Taylor, S. (2001) The OECD, globalisation and education policy (Oxford, IAU Press [The International Association of Universities \& Elsevier Science]).

Marshall, J. D. (1996) Michel Foucault: personal autonomy and education (Dordrecht, Boston, MA and London, Kluwer).

Pelgrum, W. J. \& Anderson R. E. (2001) ICT and the emerging paradigm for life-long learning: an IEA educational assessment of infrastructure, goals, and practices in twenty-six countries (2nd edn) (Amsterdam, International Association for the Evaluation of Educational Achievement).

Peters, M., Marshall, J. \& Fitzsimons, P. (2000) Managerialism and educational policy in a global context: Foucault, Neoliberalism and the doctrine of self-management, in: N.C. Burbules \& C.A. Torres (Eds) Globalization and education: critical perspectives (New York, Routledge).

Rose, N. (1999/1989) Governing the soul: the shaping of the private self (2nd edn) (London \& New York, Free Association Books). 
Simola, H., Heikkinen, S. \& Silvonen, J. (1998) A catalog of possibilities: Foucaultian history of truth and education research, in: T.S. Popkewitz \& M. Brennan (Eds) Foucault's challenge (New York \& London, Teachers College Press).

Wright, S. (2005) Processes of social transformation: an anthropology of English higher education policy, in: J. Krejsler, N. Kryger \& J. Milner (Eds) Pcedagogisk antropologi-et fag i tilblivelse (Educational anthropology - a discipline in the making) (in Danish) (Copenhagen, Danish University of Education Press). 